University of Nebraska - Lincoln

DigitalCommons@University of Nebraska - Lincoln

Agronomy \& Horticulture -- Faculty Publications

Agronomy and Horticulture Department

2018

\title{
Biomass Yield of Warm-Season Grasses Affected by Nitrogen and Harvest Management
}

\author{
Chamara S. Weerasekara \\ University of Missouri, imbulcsw@myumanitoba.ca \\ Newell R. Kitchen \\ USDA, Agricultural Research Service \\ Shibu Jose \\ Center for Agroforestry \\ Peter P. Motavalli \\ University of Missouri \\ Sougata Bardhan \\ University of Missouri
}

See next page for additional authors

Follow this and additional works at: https://digitalcommons.unl.edu/agronomyfacpub

Part of the Agricultural Science Commons, Agriculture Commons, Agronomy and Crop Sciences Commons, Botany Commons, Horticulture Commons, Other Plant Sciences Commons, and the Plant Biology Commons

Weerasekara, Chamara S.; Kitchen, Newell R.; Jose, Shibu; Motavalli, Peter P.; Bardhan, Sougata; and Mitchell, Robert B., "Biomass Yield of Warm-Season Grasses Affected by Nitrogen and Harvest Management" (2018). Agronomy \& Horticulture -- Faculty Publications. 1078.

https://digitalcommons.unl.edu/agronomyfacpub/1078

This Article is brought to you for free and open access by the Agronomy and Horticulture Department at DigitalCommons@University of Nebraska - Lincoln. It has been accepted for inclusion in Agronomy \& Horticulture -Faculty Publications by an authorized administrator of DigitalCommons@University of Nebraska - Lincoln. 


\section{Authors}

Chamara S. Weerasekara, Newell R. Kitchen, Shibu Jose, Peter P. Motavalli, Sougata Bardhan, and Robert B. Mitchell 


\title{
Biomass Yield of Warm-Season Grasses Affected by Nitrogen and Harvest Management
}

\author{
Chamara S. Weerasekara,* Newell R. Kitchen, \\ Shibu Jose, Peter P. Motavalli, Sougata Bardhan, and Robert B. Mitchell
}

\begin{abstract}
Native perennial warm-season grasses (NPWSG) have drawn interest as bioenergy feedstocks due to their high productivity with minimal amounts of inputs under a wide range of environments. Nitrogen fertility and harvest timing are critical management practices when optimizing biomass yield of NPWSG. Our objective was to quantify the impact of $\mathrm{N}$ fertilizer rate and timing in combination with harvest timing and frequency on NPWSG yield. Research was conducted in 2014 and 2015 on four field-plot locations in Missouri. The experiment was a split-plot design with three replications where $\mathrm{N}$ rate and harvest timing were the main and sub-plot treatments, respectively. Nitrogen rates were $0,34,67$, and $101 \mathrm{~kg} \mathrm{~N} \mathrm{ha}^{-1}$ with two application timings, all early spring and split $\mathrm{N}$ (early spring and following first harvest). Harvest timing included two single (September and November) and two double harvests (June followed by September or November) per year. Delaying harvest until November increased yield across sites. November harvest and $\mathrm{N}$ rates $\geq 67 \mathrm{~kg} \mathrm{ha}^{-1}$ improved NPWSG biomass yields. Although $\mathrm{N}$ fertilization improved yield, partial factor productivity (PFP) of applied $\mathrm{N}$ did not increase with annual $\mathrm{N}$ rates $>34 \mathrm{~kg} \mathrm{ha}^{-1}$. Fertilization at $67 \mathrm{~kg} \mathrm{ha}^{-1} \mathrm{yr}^{-1}$ provides an opportunity to maintain a balance between yield and $\mathrm{N}$ efficiency. These results demonstrated that $\mathrm{N}$ fertilization and harvest management of NPWSG were not always independent, and therefore these practices should be simultaneously considered. For example, early-season harvesting suppressed response to $\mathrm{N}$ when the second harvest was not delayed until after frost.
\end{abstract}

\section{Core Ideas}

- Dry matter yields increased with $\mathrm{N}$ inputs although efficiency decreased.

- Applying nitrogen at $67 \mathrm{~kg} \mathrm{~N} \mathrm{ha}^{-1}$ was superior in both yield and efficiency.

- Delaying the time of harvest until late fall or a killing frost increased yield.

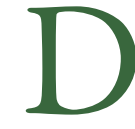

ERIVING ENERGY from plant biomass through burning and transformation to liquid or gaseous forms is a promising energy alternative that is capable of reducing reliance on fossil fuels and greenhouse gas emissions and improving rural economies (McLaughlin et al., 2002; Parrish and Fike, 2005; Simpson et al., 2008). Volatile price, uncertainties of supply, and energy security and environmental concerns associated with fossil fuels have led to significant legislation and investments toward the use of biomass energy (US Department of Energy, 2011). The Energy Independence and Security Act of 2007 and its predecessor, the Energy Policy Act of 2005 are examples of such legislation (Hochman et al., 2008). Increased attention on the use of NPWSG species including switchgrass (Panicum virgatum L.), big bluestem (Andropogon gerardii Vitman), and Indian grass [Sorghastrum nutans (L.) Nash] as bioenergy feedstocks is one of the significant results of programs such as the Herbaceous Energy Crops Research Program launched by the US Department of Energy (Wright, 1994; McLaughlin et al., 2002; McLaughlin and Kszos, 2005). Bioenergy production systems using these species are $\mathrm{C}$ negative while producing positive net energy balances due to their high yielding capacity under diverse growing conditions (Gunderson et al., 2008; Schmer et al., 2008; Mitchell et al., 2016). They even adapt well when grown on marginal landscapes which are not suitable for row crop production, have high water and nutrient use efficiency, and require minimal fertilizer and agrichemical inputs (Tilman et al., 2006; Jose and Bhaskar, 2015; Conway et al., 2017).

Perennial warm-season grasses produce multiple environmental benefits in addition to providing bioenergy feedstock. These benefits include improving water quality, soil conservation, and $\mathrm{C}$ sequestration, as well as providing wildlife habitat (McLaughlin and Walsh; 1998; McLaughlin et al., 2002; Lee et al., 2003; Simpson et al., 2008; Bardhan and Jose, 2012; Bonin et al., 2014; Mitchell et al., 2016). For example, belowground C inputs by deep, extensive root systems of switchgrass and reduced erosion led to increased soil organic $\mathrm{C}$ levels when managed as a bioenergy feedstock (Lee et al., 2007; Liebig et al., 2008).

C.S. Weerasekara, Univ. of Missouri, School of Natural Resources, Columbia, MO 65211; N.R. Kitchen, USDA-ARS, Columbia, MO 65211; S. Jose, School of Natural Resources, Center for Agroforestry, Columbia, MO 65211; P.P. Motavalli, Dep. of Soil, Environmental, and Atmos. Sci., Columbia, MO 65211; S. Bardhan, Univ. of Missouri, Center for Agroforestry, Columbia, MO 65211; R.B. Mitchell, USDA-ARS, University of Nebraska, Lincoln, NE 68583. Received 3 Apr. 2017. Accepted 2 Feb. 2018. ${ }^{*}$ Corresponding author (imbulcsw@myumanitoba.ca).

Abbreviations: AE, agronomic efficiency; DM, dry matter; NPWSG, native perennial warm-season grasses; PFP, partial factor productivity. 
Agronomic management practices play a significant role in managing NPWSG as a bioenergy feedstock by affecting the yield and composition of the harvested biomass, nutrient removal from the system, longevity of the plant stand, and anticipated environmental benefits (Waramit et al., 2011; Sadeghpour et al., 2014; Seepaul et al., 2014). Among these management practices, $\mathrm{N}$ fertilizer and harvest timing are considered critical interconnected factors in managing switchgrass as a bioenergy feedstock. Furthermore, these are the two management practices which have been studied in a significant portion of research related to bioenergy feedstock production using switchgrass (Adler et al., 2006; Lemus et al., 2008b; Anderson et al., 2013). However, the interactions of these two management factors are less studied.

Frequency and timing are the critical components of harvest management strategies when managing NPWSG, such as switchgrass, as a bioenergy crop. Research findings are mixed, as some studies indicated only one harvest per year for optimal yield and stand longevity (Sanderson et al., 1999; Parrish and Fike, 2005; Richner et al., 2014), while others indicate one or two harvests per year (Thomason et al., 2005). Systems with two harvests per year and adequate nutrient supplies allow switchgrass to be used as a dual-purpose species by providing early-season animal forage and late-season biomass feedstock (Sanderson et al., 1999; Guretzky et al., 2011; Richner et al., 2014; Seepaul et al., 2014). However, when these grasses are grown as bioenergy feedstocks, harvesting the biomass after a killing frost has shown to be more acceptable since it provides high quality feedstocks while allowing the plants to recycle nutrients in a sustainable manner by improving nutrient use efficiency (Casler and Boe, 2003; Adler et al., 2006; Seepaul et al., 2014; Wayman et al., 2014).

Nitrogen fertilization is a crucial agronomic practice which improves productivity and profitability in most food or bioenergy cropping systems (Ceotto and Di Candilo, 2010). To date, numerous studies evaluated the effects of $\mathrm{N}$ fertilization for switchgrass production. These investigations reported positive responses of switchgrass to incremental $\mathrm{N}$ applications (Vogel et al., 2002; Thomason et al., 2005; Wilson et al., 2013; Seepaul et al., 2014). In a previous study in Oklahoma, Thomason et al. (2005) reported dry matter yields of switchgrass ('Kanlow') up to $18 \mathrm{Mg} \mathrm{ha}^{-1}$ with annual $\mathrm{N}$ applications of $448 \mathrm{~kg} \mathrm{~N} \mathrm{ha}^{-1}$. However, in Iowa and Nebraska, $\mathrm{N}$ fertilization for 'Cave-inRock' switchgrass at $120 \mathrm{~kg} \mathrm{ha}^{-1}$ produced dry matter yields between 10.5 to $12.6 \mathrm{Mg} \mathrm{ha}^{-1}$ while removing approximately the same amount of $\mathrm{N}$ from the soil (Vogel et al., 2002). Investigations show that switchgrass $\mathrm{N}$ fertilizer requirements depend on the yield potential of the site, productivity of the cultivar, and harvesting schedule (McLaughlin et al., 1999; Mitchell et al., 2008; Anderson et al., 2013). Removal of a significantly greater portion of applied $\mathrm{N}$ in the two-cut system compared to single cut system (McLaughlin et al., 1999) is an example of the impact of harvesting regime on the $\mathrm{N}$ fertilizer requirement.

Although numerous studies have been conducted to investigate the individual impacts of $\mathrm{N}$ fertilizer management and harvest regime on switchgrass biomass yield, only a few studies examined these factors simultaneously (Vogel et al., 2002; Guretzky et al., 2011; Lee et al., 2013; Seepaul et al., 2014).

The objective of this study was to evaluate the impact of harvest timing, $\mathrm{N}$ management, and their interactions on the biomass yield of NPWSG on less-productive soils of Missouri with a goal of determining the optimum combination of management practices.

\section{MATERIALS AND METHODS}

\section{Study Sites}

The research was conducted during the years 2014 and 2015 in Missouri, USA. The study was conducted at four field preexisting NPWSG sites. In 2014 the sites were located in Gallatin, De Witt, Strasburg, and Green Ridge. In 2015, five sites were used with two sites in both De Witt and Strasburg and one site in Green Ridge (Table 1; Fig. 1). The sites in Gallatin and Strasburg included monocultures of big bluestem and switchgrass ('Kanlow'), respectively and there were mixtures of NPWSG in De Witt (big bluestem with Indian grass) and Green Ridge (switchgrass with Indian grass). Moreover, all of these sites have been mapped by the USDA as lands that require moderate or special conservation practices due to the limitations associated with poor drainage or high risk for erosion. The 30-yr average precipitation and monthly values received at each site during the experimental period were obtained from the nearest National Weather Service station to the site from a weather database maintained by the Utah State University (2016), and are graphically represented in Fig. 2.

\section{Experimental Design and Management Practices}

Experiment was designed as a randomized complete block split-plot experimental design with three replicates, with $\mathrm{N}$ (rate and timing combined) as the main plot ( $8 \mathrm{~m}$ by $3 \mathrm{~m}$ ) and harvest as sub-plot $(2 \mathrm{~m}$ by $3 \mathrm{~m})$ treatments. Ammonium nitrate $\left(\mathrm{NH}_{4} \mathrm{NO}_{3}\right)$ was used as the $\mathrm{N}$ source and applied at three rates $\left(34,67\right.$, and $\left.101 \mathrm{~kg} \mathrm{~N} \mathrm{ha}^{-1} \mathrm{yr}^{-1}\right)$ in May of each year. Furthermore, 67 and $101 \mathrm{~kg} \mathrm{~N} \mathrm{ha}^{-1} \mathrm{yr}^{-1}$ treatments were also applied as split applications (67 $\mathrm{kg} \mathrm{N} \mathrm{ha}^{-1} \mathrm{yr}^{-1}, 0.5: 0.5 \mathrm{May} / \mathrm{June}$ split application; $101 \mathrm{~kg} \mathrm{~N} \mathrm{ha}^{-1} \mathrm{yr}^{-1}, 0.67: 0.33 \mathrm{May} / \mathrm{June}$ split application, and 0.33:0.67 May/June split application) (Table 2). Nitrogen fertilizer was pre-weighed and hand-broadcasted uniformly over each treated plot. There were two zero $\mathrm{N}$ fertilizer treatments. One of them had native legumes added to NPWSG to potentially add $\mathrm{N}$ without fertilizer $\mathrm{N}$ inputs, and the other was without legumes or $\mathrm{N}$ fertilizer, to provide an overall $\mathrm{N}$ control (Table 2). There were four harvest timing treatments (Table 2) with two two-cut and two one-cut harvests which include both timing and frequency aspects of harvesting management. Both two-cut harvest treatments applied the first cut in mid- to late June and the second cut was either September or November. At sites De Witt 1, Green Ridge, and Strasburg 1, the above treatments were applied on the same plots in both years 2014 and 2015.

\section{Sampling and Data Collection}

For harvesting, a $0.7-\mathrm{m}$ swath of grass was harvested from each 3-m long experimental unit using a sickle-bar mower (BCS model 710, BCS America, Portland, OR) leaving a 10-cm stubble height. The wet biomass weight of the harvested grass was measured and a representative subsample was collected from each plot. Subsamples were measured for the fresh 


\begin{tabular}{|c|c|c|c|c|c|}
\hline Site & Year & Soil & $\begin{array}{c}\text { Landscape } \\
\text { position, slope, } \\
\text { and capability } \\
\text { class } \dagger\end{array}$ & $\begin{array}{l}\text { Grass } \\
\text { composition } \\
(\%) \ddagger\end{array}$ & $\begin{array}{l}\text { Site management } \\
\text { history prior to investigation }\end{array}$ \\
\hline $\begin{array}{l}\text { DeWitt I } \\
\left(39^{\circ} 22^{\prime} \mathrm{N}\right. \\
\left.93^{\circ} 17^{\prime} \mathrm{W}\right)\end{array}$ & $2014 / 2015$ & $\begin{array}{c}\text { Nodaway silt loam } \\
\text { (Fine-silty, mixed, } \\
\text { superactive, nonacid, } \\
\text { mesic Mollic Udifluvents) }\end{array}$ & $\begin{array}{l}\text { Foot slope, } \\
0-5 \%, 3-w\end{array}$ & $\begin{array}{l}\text { Indian grass } \\
(60), \\
\text { Big bluestem } \\
(40)\end{array}$ & $\begin{array}{l}\text { Established in July } 200 \mathrm{I} \text {; planted at } 9 \mathrm{~kg} \\
\text { PLS§ ha- }{ }^{-1} \text { no chemical weed control; no fertilizer prior } \\
\text { to this study; burned during winter every third year } \\
\text { prior to this study and every year during the study. }\end{array}$ \\
\hline $\begin{array}{l}\text { DeWitt } 2 \\
\left(39^{\circ} 22^{\prime} \mathrm{N}\right. \\
\left.93^{\circ} 17^{\prime} \mathrm{W}\right)\end{array}$ & 2015 & $\begin{array}{l}\text { Wakenda silt loam } \\
\text { (Fine-silty, } \\
\text { mixed, superactive, } \\
\text { mesic Typic Argiudolls) }\end{array}$ & $\begin{array}{l}\text { Summit, } \\
2-9 \%, 3-e\end{array}$ & $\begin{array}{l}\text { Indian grass } \\
(70), \\
\text { Big bluestem } \\
(30)\end{array}$ & $\begin{array}{l}\text { Established in July } 200 \mathrm{I} \text {; planted at } 9 \mathrm{~kg} \mathrm{PLS} \mathrm{ha}^{-1} \text {; } \\
\text { no chemical weed control; no fertilizer prior } \\
\text { to this study; burned during winter every third } \\
\text { year until 2008, then hayed after fall dormancy for } \\
2009-20 \mathrm{II} \text {, then burned during winter for } 20 \mathrm{I} 2-20 \mathrm{I} \text {. }\end{array}$ \\
\hline $\begin{array}{l}\text { Gallatin } \\
\left(39^{\circ} 51^{\prime} \mathrm{N}\right. \\
\left.93^{\circ} 58^{\prime} \mathrm{W}\right)\end{array}$ & 2014 & $\begin{array}{l}\text { Mandeville silt loam (Fine- } \\
\text { loamy, mixed, superactive, } \\
\text { mesic Typic Hapludalfs) }\end{array}$ & $\begin{array}{l}\text { Side slope, } \\
\text { 2-30\%, 3-e }\end{array}$ & $\begin{array}{l}\text { Big bluestem } \\
(100)\end{array}$ & 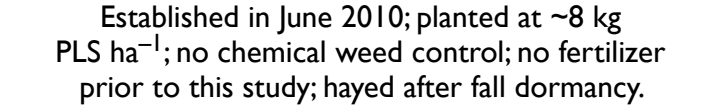 \\
\hline $\begin{array}{l}\text { Green Ridge } \\
\left(38^{\circ} 36^{\prime} \mathrm{N}\right. \\
\left.93^{\circ} 21^{\prime} \mathrm{W}\right)\end{array}$ & $2014 / 2015$ & $\begin{array}{l}\text { Hartwell silt loam } \\
\text { (Fine, mixed, active, } \\
\text { thermic Typic Argialbolls) }\end{array}$ & $\begin{array}{l}\text { Summit, } \\
0-5 \%, 2-w\end{array}$ & $\begin{array}{l}\text { Switchgrass } \\
\quad(50), \\
\text { Indian grass (50) }\end{array}$ & $\begin{array}{l}\text { Established in 1988; planted at } \sim 8 \mathrm{~kg} \text { PLS ha-1; } \\
\text { no chemical weed control; no fertilizer prior } \\
\text { to this study; burned after year3 then annually. }\end{array}$ \\
\hline $\begin{array}{l}\text { Strasburg I } \\
\left(38^{\circ} 45^{\prime} \mathrm{N}\right. \\
\left.94^{\circ} 9^{\prime} \mathrm{W}\right)\end{array}$ & $2014 / 2015$ & $\begin{array}{l}\text { Haig silt loam } \\
\text { (Fine, smectitic, } \\
\text { mesic Vertic Argiaquolls) }\end{array}$ & $\begin{array}{l}\text { Summit, } \\
0-2 \%, 2-w\end{array}$ & $\begin{array}{l}\text { Switchgrass } \\
\quad(100)\end{array}$ & $\begin{array}{l}\text { Established in early May 20I0; planted at } \\
\sim 7 \mathrm{~kg} \text { PLS ha-I; weed control:Year I: labeled } \\
\text { rate of glyphosate in late Apr, mowing in late Jun, } \\
\text { labeled rate of dicamba+2,4-D in late July, Year } 2 \\
\text { and 3: labeled rate of atrazine+alachlor in early May; } \\
\text { fertilized during the first } 3 \text { yr with } \sim 56,22 \text {, and } 67 \mathrm{~kg} \\
\mathrm{ha}^{-1} \text { of } \mathrm{N}, \mathrm{P}_{2} \mathrm{O}_{5} \text {, and } \mathrm{K}_{2} \mathrm{O} \text {, respectively; hayed spring } \\
\text { and fall of } 20 \mathrm{II}^{\mathrm{I}} \text { and burned in the early spring of } 20 \mathrm{I} 3 .\end{array}$ \\
\hline $\begin{array}{l}\text { Strasburg } 2 \\
\left(38^{\circ} 45^{\prime} \mathrm{N}\right. \\
\left.94^{\circ} 9^{\prime} \mathrm{W}\right)\end{array}$ & 2015 & $\begin{array}{l}\text { Sampsel silty clay loam } \\
\text { (Fine, smectitic, mesic } \\
\text { Vertic Argiaquolls) }\end{array}$ & $\begin{array}{l}\text { Side slope, } \\
2-14 \% \text {, 3-e }\end{array}$ & $\begin{array}{c}\text { Switchgrass } \\
(100)\end{array}$ & (same as Strasburg I) \\
\hline
\end{tabular}

† Number in the capability class denotes the need for soil conservation practices. Greater the number, more careful conservation measures are recommended. The letter represents the predominant cause of marginal conditions of the land. e; erosion and w; excessive wetness (Soil Survey Staff, 20I4). $\ddagger$ Grass species composition was performed based on visual evaluation of each filed and expressed as the relative percentage of plants per unit area. $\S \mathrm{PLS}$, pure live seeds.

weight and dried in a forced air oven at $55^{\circ} \mathrm{C}$ for $72 \mathrm{~h}$ for dry matter (DM) yield determination.

\section{Nitrogen Use Metrics}

Agronomic efficiency (AE) and partial factor productivity (PFP) of applied $\mathrm{N}$ were estimated using the following equations presented by Dobermann (2007).

$$
\begin{aligned}
& \text { PFP }=\frac{\mathrm{kg} \text { biomass } \mathrm{ha}^{-1}}{\mathrm{~kg} \text { total applied } \mathrm{N} \mathrm{ha}^{-1}} \\
& \mathrm{AE}=\frac{\text { Yield at } \mathrm{N}_{\mathrm{x}}-\text { Yield at } \mathrm{N}_{0}}{\mathrm{~kg} \text { total applied } \mathrm{N} \mathrm{ha}^{-1}}
\end{aligned}
$$

where, $\mathrm{N}_{\mathrm{x}}=\mathrm{N}$ rate $>0$, and $\mathrm{N}_{0}=$ control or no $\mathrm{N}$ application.

\section{Statistical Analysis}

Data were analyzed using the GLIMMIX procedure of SAS (SAS Institute, 2011) to determine significant $(P \leq 0.05)$ treatment effects. Dependent variables were DM, AE, and PFP. Nitrogen treatment, harvest management, and their interaction were considered fixed effects, and the interactions of fixed effects with block were considered random. Due to unique NPWSG species composition at each location, and because only one-half of the sites had 2 yr of data, both site and year

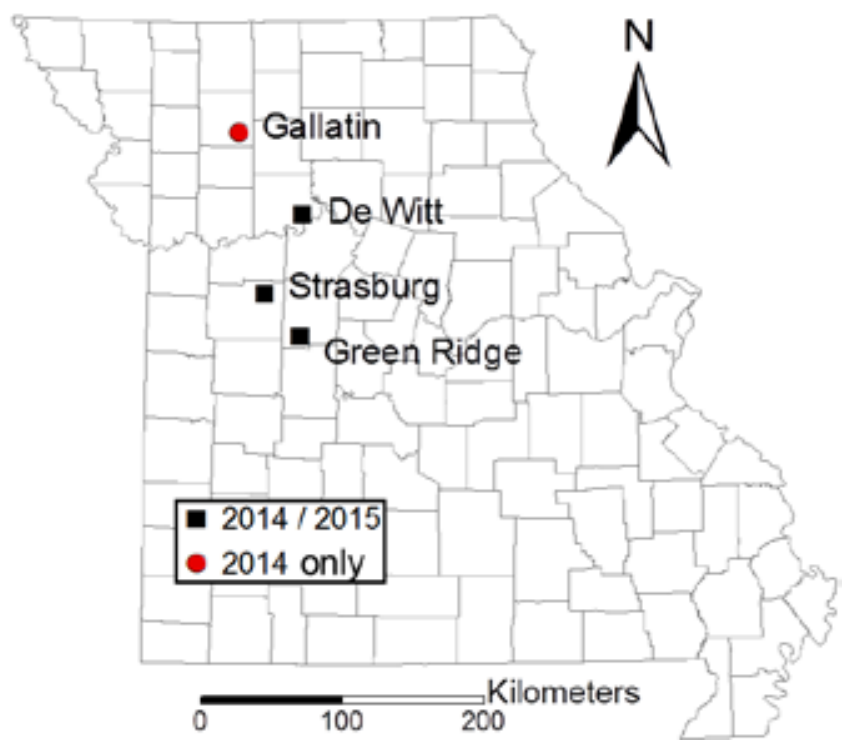

Fig. I. Location of the field sites and the years of operation. 

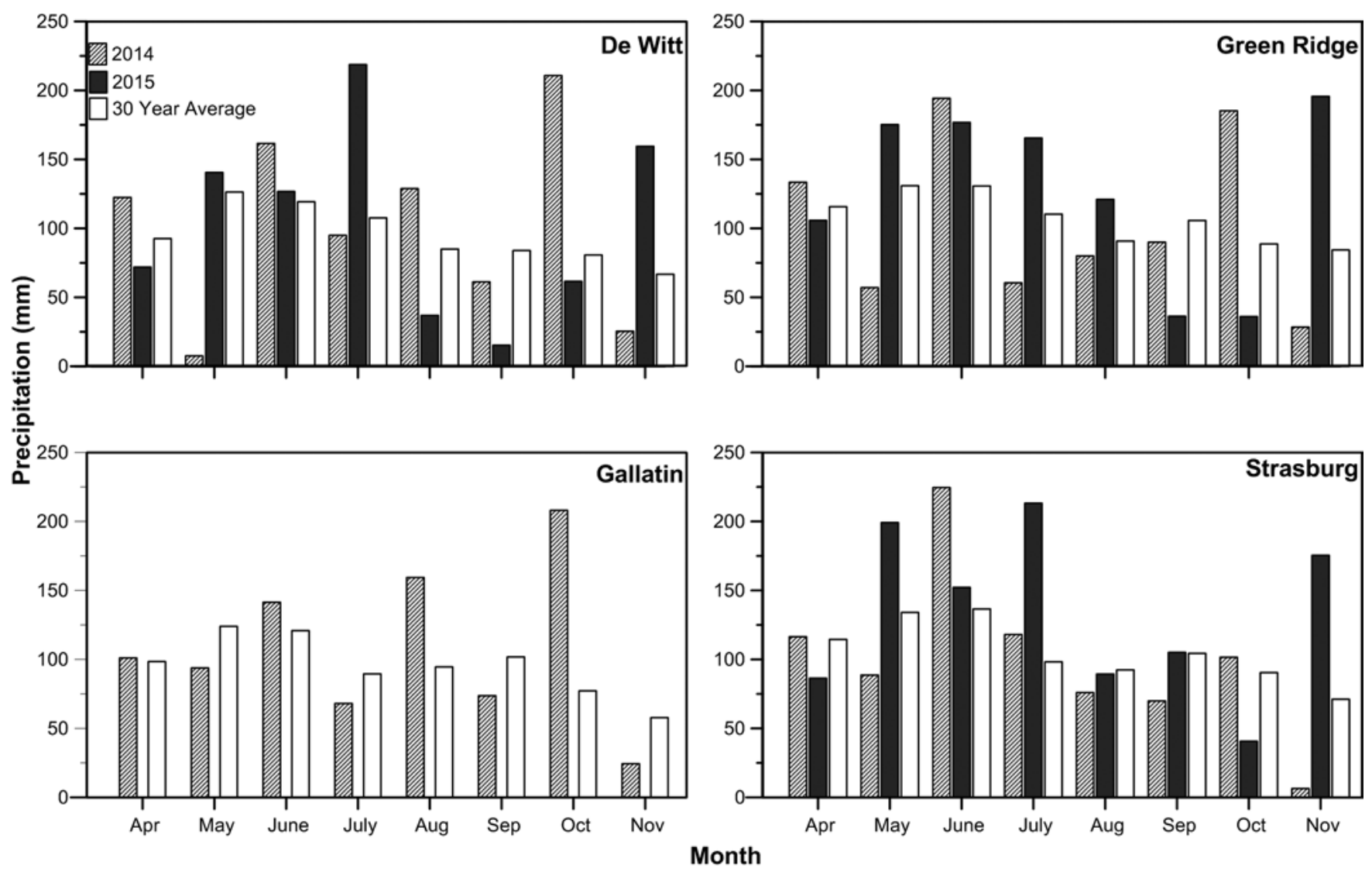

Fig. 2. Monthly precipitation for study locations in 2014 and 2015 and 30-yr long term average.

were excluded from the model. Tukey's honest significant difference (HSD) was used for mean separations at $\alpha=0.05$.

\section{RESULTS AND DISCUSSION}

\section{Biomass Yield}

The impact of $\mathrm{N}$ and harvest timing management, as well as their interactions, varied by site and year (Table 3). Generally, NPWSG yield increased with $\mathrm{N}$ fertilization (exception at Gallatin in 2014). Likewise, harvest timing management always impacted yield. Sites resulting in $\mathrm{N}$ rate by harvest timing interactions are discussed separately below.

\section{Nitrogen Effect}

Nitrogen fertilization positively impacted grass biomass yields both years (Fig. 3). Four of five of the $\mathrm{N}$ responsive sites had yield increases of at least $3 \mathrm{Mg} \mathrm{ha}^{-1}$. A plateau of biomass yields above $\mathrm{N}$ levels of $67 \mathrm{~kg} \mathrm{ha}^{-1}$ was observed at De Witt 1 and Green Ridge in 2014 and Strasburg 2 in 2015, while yield plateaued after $34 \mathrm{~kg} \mathrm{ha}^{-1}$ at both sites in De Witt in 2015. Furthermore, at all the $\mathrm{N}$ responsive sites application of $\mathrm{N}$ at 67 or $101 \mathrm{~kg} \mathrm{ha}^{-1}$ produced superior yields $\left(5.8-11.1 \mathrm{Mg} \mathrm{ha}^{-1}\right)$ compared to $34 \mathrm{~kg} \mathrm{~N} \mathrm{ha}^{-1}$ and non-fertilized plots (3.5-8.6 $\left.\mathrm{Mg} \mathrm{ha}^{-1}\right)$. Except for the two sites in De Witt in 2015, this observation is in accordance with an indication of a yield plateau of switchgrass biomass yield with an application of $\mathrm{N}$ at $67 \mathrm{~kg} \mathrm{ha}^{-1}$ as reported by Haque et al. (2009).

Though not statistically tested, biomass yields at De Witt 1 were generally 2 to $3 \mathrm{Mg} \mathrm{ha}^{-1}$ more in 2014 than 2015 . For example, the range of biomass yields in 2014 and 2015 were
5.9 to $9.9 \mathrm{Mgha}^{-1}$ and 3.5 to $6.9 \mathrm{Mg} \mathrm{ha}^{-1}$, respectively. This variation of biomass yield in $2 \mathrm{yr}$ can be attributed to seasonal flooding occurred due to the excessive precipitation received in the months of May and July for 2015 (141 and $219 \mathrm{~mm}$, respectively) relative to that received in 2014 (8 and $95 \mathrm{~mm}$, respectively) (Fig. 2). In addition, soil of the De Witt 1 site was poorly drained, and developed along a small stream (Udifluvent). In growing seasons with frequent and high precipitation there is a great potential for $\mathrm{N}$ to being lost through denitrification rather than leaching due to poor soil drainage conditions (Table 1) at the site (Cameron et al., 2013). Apart from the losses of applied $\mathrm{N}$, plant stress induced by flooded conditions in the field may have negatively affected the biomass yield (Scott and Sallam, 1987; Sharma et al., 1990; Moraghan and Smith, 1996; Alam, 1999). Furthermore, in 2014 at De Witt 1, 101, and $67+34 \mathrm{~kg}$ $\mathrm{ha}^{-1}$ gave significantly higher biomass yields compared to nonfertilized (control and legume) and $34 \mathrm{~kg} \mathrm{~N} \mathrm{ha}^{-1}$ treatments. In 2015 at De Witt 1, the split application of $67+34 \mathrm{~kg} \mathrm{ha}^{-1}$ produced biomass yield significantly greater compared with $34+34 \mathrm{~kg} \mathrm{ha}^{-1}$ and non-fertilized plots while the yields from both 101 and $34+67 \mathrm{~kg} \mathrm{ha}^{-1}$ were greater compared to control and legume. In contrast, the De Witt 2 was an upland site and located on a back-slope of the landscape with soils that are better drained. Here, biomass yields in 2015 were generally higher (not statistically tested) under each $\mathrm{N}$ treatment compared to De Witt 1 site $\left(4.6-8.6\right.$ vs. $\left.3.5-6.9 \mathrm{Mg} \mathrm{ha}^{-1}\right)$. This difference can be attributed to the differences in soil drainage conditions (well drained at De Witt 2 vs. poorly drained at De Witt 1) and landscape characteristics ( $>5 \%$ slope at De Witt 2 vs. $<1 \%$ slope at De Witt 1). When considering the biomass yield performance 
Table 2. Summary of the $\mathrm{N}$ and harvest treatments applied in the research.

\begin{tabular}{|c|c|c|c|c|c|c|}
\hline \multicolumn{4}{|c|}{$\mathrm{N} /$ main-plot treatments } & \multicolumn{3}{|c|}{ Harvest/sub-plot treatments } \\
\hline \multirow{2}{*}{$\begin{array}{l}N \text { trt } \\
\text { ID }\end{array}$} & \multicolumn{2}{|c|}{$\begin{array}{c}\text { Time of } \\
\text { application }\end{array}$} & \multirow{2}{*}{$\begin{array}{c}\text { Total } \\
\text { inorganic } \\
\mathrm{N} \text { per year }\end{array}$} & \multirow{2}{*}{$\begin{array}{c}\text { Harvest } \\
\text { trt ID }\end{array}$} & \multicolumn{2}{|c|}{ Time of harvest } \\
\hline & May & June & & & First cut & Second cut \\
\hline & 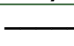 & $\mathrm{kg} \mathrm{N}$ & $\mathrm{ha}^{-\mathrm{I}}$ & & & \\
\hline \multirow[t]{4}{*}{0} & 0 & 0 & 0 & $\mathrm{~J} / \mathrm{S}$ & June & September \\
\hline & & & & $S$ & September & - \\
\hline & & & & $\mathrm{J} / \mathrm{N}$ & June & November \\
\hline & & & & $\mathrm{N}$ & November & - \\
\hline \multirow[t]{4}{*}{$\mathrm{L} \dagger$} & 0 & 0 & 0 & $\mathrm{~J} / \mathrm{S}$ & June & September \\
\hline & & & & $S$ & September & - \\
\hline & & & & $J / N$ & June & November \\
\hline & & & & $N$ & November & - \\
\hline \multirow[t]{4}{*}{34} & 34 & 0 & 34 & $\mathrm{~J} / \mathrm{S}$ & June & September \\
\hline & & & & $\mathrm{S}$ & September & - \\
\hline & & & & $\mathrm{J} / \mathrm{N}$ & June & November \\
\hline & & & & $\mathrm{N}$ & November & - \\
\hline \multirow[t]{4}{*}{67} & 67 & 0 & 67 & $\mathrm{~J} / \mathrm{S}$ & June & September \\
\hline & & & & $S$ & September & - \\
\hline & & & & $\mathrm{J} / \mathrm{N}$ & June & November \\
\hline & & & & $\mathrm{N}$ & November & - \\
\hline \multirow[t]{4}{*}{$34+34$} & 34 & 34 & 67 & $\mathrm{~J} / \mathrm{S}$ & June & September \\
\hline & & & & $S$ & September & - \\
\hline & & & & $\mathrm{J} / \mathrm{N}$ & June & November \\
\hline & & & & $N$ & November & - \\
\hline \multirow[t]{4}{*}{101} & 101 & 0 & 101 & $\mathrm{~J} / \mathrm{S}$ & June & September \\
\hline & & & & $S$ & September & - \\
\hline & & & & $\mathrm{J} / \mathrm{N}$ & June & November \\
\hline & & & & $\mathrm{N}$ & November & - \\
\hline \multirow[t]{4}{*}{$67+34$} & 67 & 34 & 101 & $\mathrm{~J} / \mathrm{S}$ & June & September \\
\hline & & & & $S$ & September & - \\
\hline & & & & $\mathrm{J} / \mathrm{N}$ & June & November \\
\hline & & & & $\mathrm{N}$ & November & - \\
\hline \multirow[t]{4}{*}{$34+67$} & 34 & 67 & 101 & $\mathrm{~J} / \mathrm{S}$ & June & September \\
\hline & & & & $S$ & September & - \\
\hline & & & & $\mathrm{J} / \mathrm{N}$ & June & November \\
\hline & & & & $\mathrm{N}$ & November & - \\
\hline
\end{tabular}

$\nmid \mathrm{L}$, native legumes (Patridge pea [Chamaecrista fasciculate] and Illinois bundleflower [Desmanthus illinoensis] seeds were sown in May 2014).

under each $\mathrm{N}$ management at De Witt 2 in 2015, 34+34, 101, and $67+34 \mathrm{~kg} \mathrm{ha}^{-1}$ dominated over non-fertilized.

At Green Ridge in 2014, the applications of 67+34, 101, $34+67$, and $67 \mathrm{~kg} \mathrm{ha}^{-1}$ performed better compared with the control, legume, and $34 \mathrm{~kg} \mathrm{ha}^{-1} \mathrm{~N}$ treatments (Fig. 3). In addition, for 2015 at Strasburg 2, 67, and $101 \mathrm{~kg} \mathrm{ha}^{-1}$ were significantly higher than the control, legume, and $34 \mathrm{~kg} \mathrm{ha}^{-1}$. However, for these two sites, there were no significant differences in biomass yields when comparing one-time and split $\mathrm{N}$ application strategies when fertilizing at $\mathrm{N}$ rates of 67 and $101 \mathrm{~kg} \mathrm{ha}^{-1}$.

Variable response of biomass yield of NPWSG to N fertilization was observed throughout this study. This variability can be attributed to the differences in weather (especially precipitation), soil productivity caused by landscape characteristics, grass stand characteristics including species compositions or cultivars and stand density, and harvest timing strategies (Casler and Boe, 2003; Thomason et al., 2005; Lemus et al., 2008b; Mulkey et al., 2008; Guretzky et al., 2011; Vogel et al., 2010). In
Table 3. Fixed effects $(P<F)$ of $\mathrm{N}$ rate and timing combinations, harvest timing, and their interactions on dry matter yield at each site in each year.

\begin{tabular}{lcccc}
\hline & & \multicolumn{3}{c}{ Source of variation } \\
\cline { 3 - 5 } Year & Site & $\mathrm{N}$ & Harvesting & $\mathrm{N} \times$ Harvesting \\
\hline 2014 & DeWitt I & 0.040 & $<0.00 \mathrm{I}$ & 0.28 \\
& Gallatin & 0.24 & $<0.00 \mathrm{I}$ & 0.28 \\
& Green Ridge & $<0.00 \mathrm{I}$ & $<0.00 \mathrm{I}$ & 0.15 \\
& Strasburg I & $<0.00 \mathrm{I}$ & $<0.00 \mathrm{I}$ & $<0.00 \mathrm{I}$ \\
& DeWitt I & $<0.00 \mathrm{I}$ & $<0.00 \mathrm{I}$ & 0.15 \\
& DeWitt 2 & $<0.0 \mathrm{I}$ & $<0.00 \mathrm{I}$ & 0.76 \\
& Green Ridge & $<0.00 \mathrm{I}$ & $<0.001$ & $<0.0 \mathrm{I}$ \\
& Strasburg I & $<0.00 \mathrm{I}$ & $<0.001$ & 0.040 \\
& Strasburg 2 & $<0.01$ & $<0.001$ & 0.34 \\
\hline
\end{tabular}

addition, carry-over effects of the $\mathrm{N}$ treatments from 2014 may have partly impacted the variability in biomass yields in 2015 at De Witt 1, Green Ridge and Strasburg 1. Therefore, careful and site-specific decision making on $\mathrm{N}$ fertility management while taking energy, economic, environmental costs in addition to above factors is necessary for making these warm-season grass bioenergy feedstocks production systems sustainable.

\section{Harvest Timing Effect}

Harvest timing influenced biomass yield at all the sites (Table 3; Fig. 4). At each site in both years, greater biomass yields were associated of harvesting that generally included a late fall or November harvest (November and June+November) (Fig. 4). In contrast, harvest timing strategies which typically corresponded with early fall (September and June+September) produced lower biomass yields than the late fall harvest. This variation of biomass yields can be attributed to the extended biomass growth that occurred during fall months (June to November). Late fall harvest strategies can be much more sustainable due to both higher biomass yields and reduced annual $\mathrm{N}$ inputs as a result of remobilization of considerable $\mathrm{N}$ from aboveground to the belowground root structures (Vogel et al., 2002; Wayman et al., 2014). Apart from that, biomass moisture levels were generally between 12 and $13 \%$ for November harvests, typical for November harvested biomass (Ogden et al., 2010) and that makes biomass suitable for transportation and storage without risks of undergoing composition degradation and spontaneous combustion (Mitchell and Schmer, 2012).

On a site-by-site basis when comparing the two single cut harvest strategies (September and November), yields were significantly greater with the November harvest than the September harvest, except at the Gallatin site where overall productivity was the lowest of all the sites (Fig. 4). Over all sites, delaying harvest to November resulted in a 28 to $51 \%$ increase in yield compared to the September harvest. Similarly, when contrasting the 2-cut harvest management strategies, the June+November system always out-yielded the June+September system. Averaged over all sites this was a 50 to $200 \%$ increase over the June+September harvest. It is apparent the difference in biomass yields between these harvest systems can be attributed to the contribution of biomass coming from the growth between September and November. The benefit of $\mathrm{N}$ recycling back into roots would also be more realized with the June+November practice. 

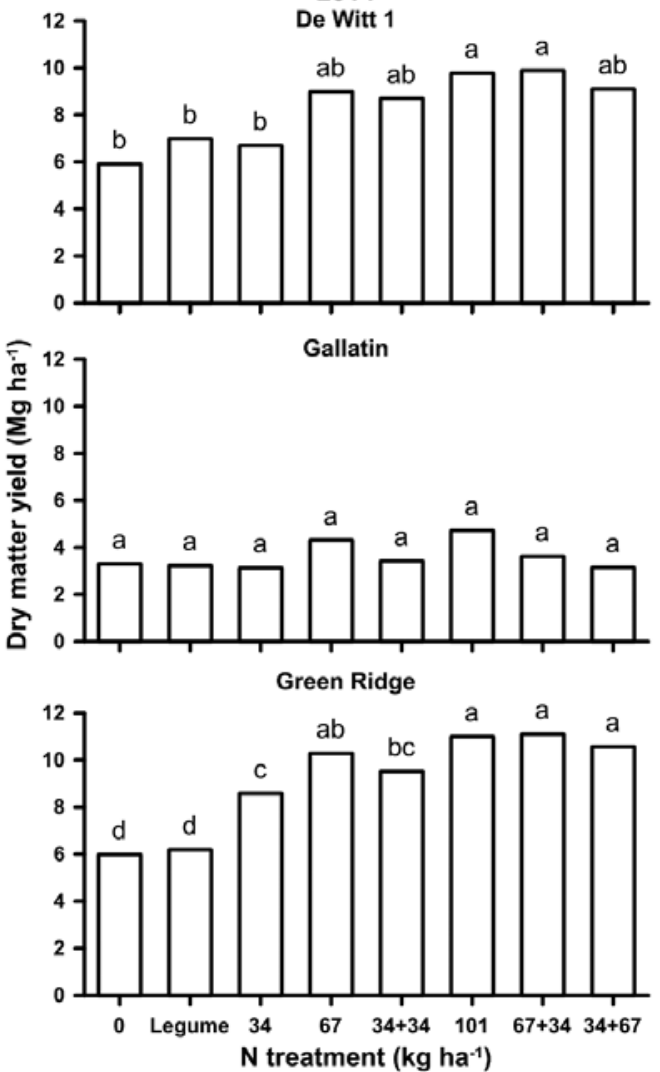

2015

De Witt 1
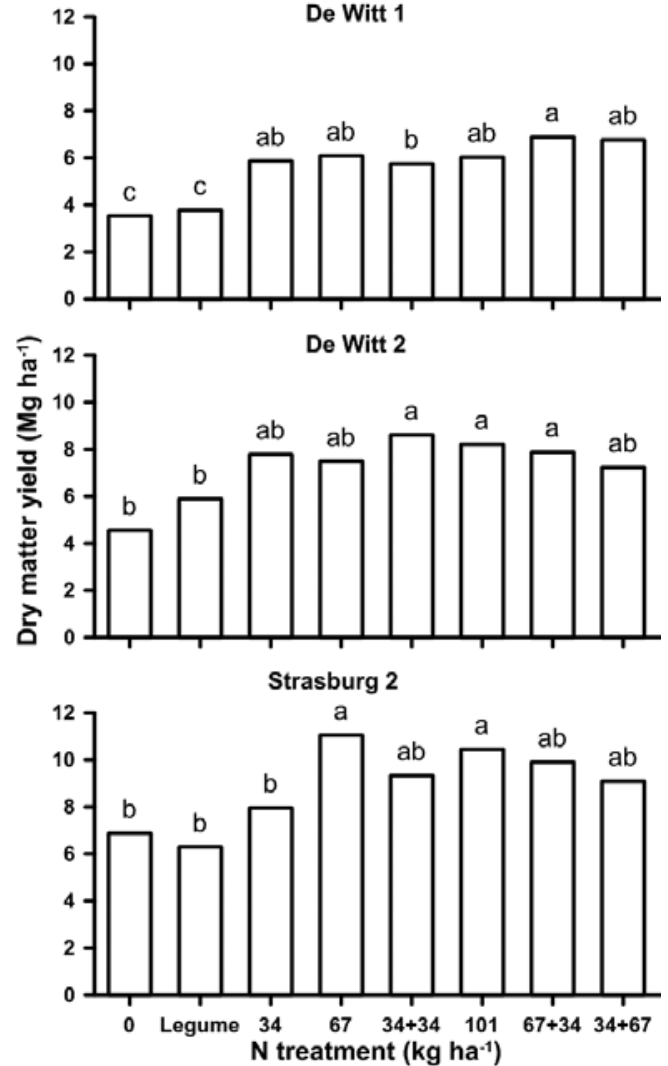

Fig. 3. Main effect of nitrogen rate and timing combinations on the dry matter yield at each site in 2014 and 2015 . Columns with the same letter are not significantly different at $P \leq 0.05$.

In 2015, De Witt 2 was the only site where biomass yields were greater with the 1-cut November harvest management over the 2-cut June+November harvest management (Fig. 4). With all sites except De Witt 1 in 2014, an early summer harvest (June) along with a September harvest resulted in lowest biomass yields compared to the other management strategies. Thus, harvesting feedstock for animals in June necessitates allowing the warm season grass to grow throughout the entire fall until after cold dormancy has been initiated (November harvest) without causing a growing-season yield drag.

\section{Interactions of Nitrogen and Harvest Timing}

Interaction of $\mathrm{N}$ and harvesting timing influenced dry matter yield of grasses at Green Ridge in 2015 and at Strasburg 1 in both years (Table 3; Fig. 5). Early harvesting of biomass suppressed response to $\mathrm{N}$ when the second harvest was not delayed until after frost. However, at Green Ridge supplementing $\mathrm{N}$ at $101 \mathrm{~kg}$ $\mathrm{ha}^{-1}$ as a single application with June+September harvest timing regime produced the highest dry matter yield $\left(6.2 \mathrm{Mg} \mathrm{ha}^{-1}\right)$ and it was significantly greater than the control $\left(3.3 \mathrm{Mg} \mathrm{ha}^{-1}\right)$. With a harvest timing strategy of June+November, an exponential increase of dry matter yields was observed with increasing $\mathrm{N}$ supplies at each site. Conversely, with a single harvest in September (Sep), biomass yields tended to plateau at $67 \mathrm{~kg} \mathrm{ha}^{-1}$. Furthermore, at each site across all the $\mathrm{N}$ management strategies, a single harvest in November produced significantly higher dry matter yields compared to June+September harvest timing strategy.
The variation of biomass yields associated with harvest strategy can be attributed to the prolonged and sustained uptake of applied $\mathrm{N}$ associated with June+November and November harvest strategies. Because growth was more optimal with these, the risk of environmental losses of $\mathrm{N}$ via leaching and runoff was less for these harvest strategies than for both June+September and September harvest practices.

The ratio of regrowth to the first cut yields in double harvest strategies were 0.3 to 1.4 and 0.5 to 2.9 for June+September and June+November, respectively. Additionally, relative to June+November harvesting for 2014 at Strasburg 1, the control, legume, and $34 \mathrm{~kg} \mathrm{ha}^{-1}, \mathrm{~N}$ management strategies had regrow th yield ratios relative to the first cut of less than 1.0 $(0.5,0.7$, and 0.9 , respectively). The same ratio with each split $\mathrm{N}$ application strategy ranged between 0.4 to 1.4 and 1.4 to 2.9 with June+September and June+November harvest strategies. This result implies that late fall harvest of two-cut harvest systems was taking advantage of split applied N.

Under each harvest strategy, split application of $\mathrm{N}$ at both rates 67 and $101 \mathrm{~kg} \mathrm{ha}^{-1}$ per growing season did not improve biomass yields compared to one-time application strategies. Moreover, $\mathrm{N}$ fertilizer application and harvesting of biomass are among the most energy and time consuming operations in cellulosic biomass feedstock production. Therefore, these results do not support split application of $\mathrm{N}$ while practicing two harvests per growing season, as others have suggested (Vogel et al., 2002; Vogel et al., 2010). 
Partial factor productivity is an index of $\mathrm{N}$ use efficiency that integrates the use efficiency of both indigenous and applied $\mathrm{N}$ (Dobermann, 2007). Nitrogen fertility management impacted PFP at all the sites during both 2014 and 2015 (Table 4; Fig. 6). Furthermore, the variation of PFP relative to the $\mathrm{N}$ management followed a similar trend at all the sites in both years. Highest PFP (90-250 kg biomass kg-1 N) was associated with application of $34 \mathrm{~kg} \mathrm{~N} \mathrm{ha}^{-1}$ and the lowest $(30-110 \mathrm{~kg}$ biomass $\mathrm{kg}^{-1} \mathrm{~N}$ ) with $101 \mathrm{~kg} \mathrm{~N} \mathrm{ha}^{-1}$. At almost all the sites, PFP with application of $\mathrm{N}$ in split applications at the rates of $67 \mathrm{~kg} \mathrm{ha}^{-1}$ $\left(34+34 \mathrm{~kg} \mathrm{ha}^{-1}\right)$ and $101 \mathrm{~kg} \mathrm{~N} \mathrm{ha}^{-1}(67+34$ and $34+67 \mathrm{~kg}$ $\mathrm{ha}^{-1}$ ) was slightly reduced compared to one-time application, but this was never statistically different.

\section{Agronomic Efficiency}

Agronomic efficiency is the yield increase in response to the unit amount of applied N (Dobermann, 2007). The AE of applied $\mathrm{N}$ was affected by $\mathrm{N}$ fertilization at both sites at De Witt in 2015 (Table 4; Fig. 7). The highest AE values were associated with $34 \mathrm{~kg} \mathrm{~N} \mathrm{ha}^{-1}$ at both the sites $\left(68\right.$ and $95 \mathrm{~kg}$ biomass kg${ }^{-1}$ $\mathrm{N})$. Furthermore, at De Witt 1 the AE with $34 \mathrm{~kg} \mathrm{~N}^{-1}$ was significantly greater than all other $\mathrm{N}$ treatments, while at $\mathrm{De}$ Witt 2 there was no significant difference between $34 \mathrm{~kg} \mathrm{~N} \mathrm{ha}^{-1}$ $\left(95 \mathrm{~kg}\right.$ biomass kg$\left.{ }^{-1} \mathrm{~N}\right)$ and split application of $\mathrm{N}$ at $67 \mathrm{~kg} \mathrm{ha}^{-1}$ $\left(60 \mathrm{~kg}\right.$ biomass $\left.\mathrm{kg}^{-1} \mathrm{~N}\right)$. However, at De Witt 2, AE with $34 \mathrm{~kg}$

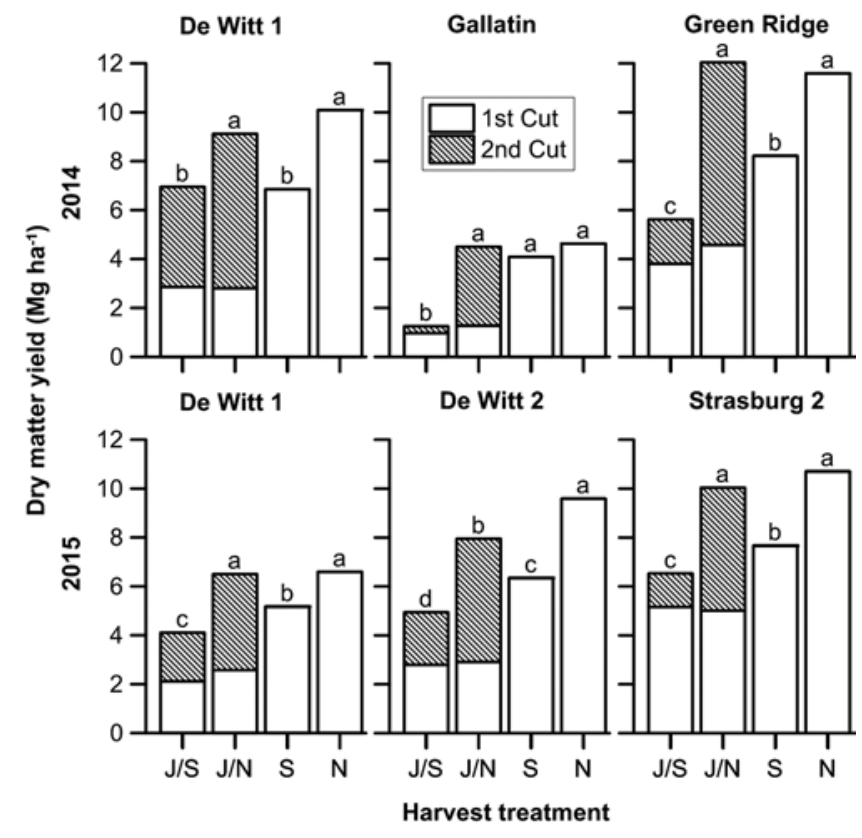

Fig. 4. Main effects of harvest treatments at each site in 2014 and 20I5. Harvest treatments included: J/S, June+September harvest; J/N, June+November harvest; S, September harvest; and $\mathrm{N}$, November harvest. Columns with the same letter are not significantly different at $P \leq 0.05$.
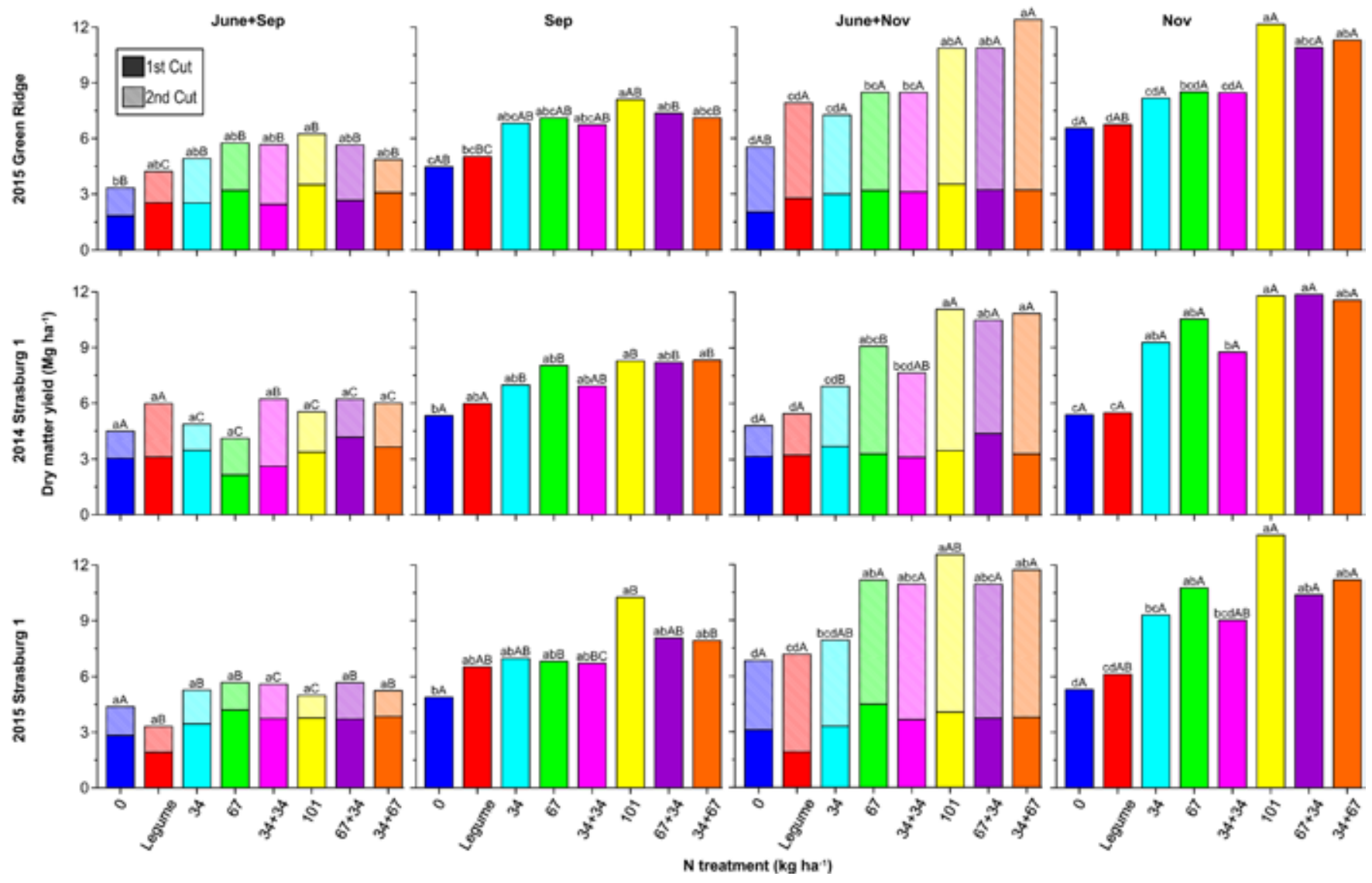

Fig. 5. Interaction of $\mathrm{N}$ and harvest timing on dry matter yield at Green Ridge in $20 \mathrm{I} 5$ and at Strasburg I in 20I4 and 20I5. Columns with the same letter are not significantly different at $P \leq 0.05$. Different lowercase letters denote differences between each $N$ treatment within each harvest strategy; different uppercase letters denote differences between each harvest strategy within each $\mathrm{N}$ treatment. 
Table 4. Fixed effects $(P<F)$ of $\mathrm{N}$ rate on $\mathrm{N}$ use metrics at each site in each year.

\begin{tabular}{|c|c|c|}
\hline \multirow[b]{2}{*}{ Year } & \multirow[b]{2}{*}{ Site } & \multirow{2}{*}{$\begin{array}{c}\text { Source of variation } \\
\mathrm{N}\end{array}$} \\
\hline & & \\
\hline & Partial F & ductivity \\
\hline \multirow[t]{4}{*}{2014} & De Witt I & $<0.01$ \\
\hline & Gallatin & $<0.001$ \\
\hline & Green Ridge & $<0.001$ \\
\hline & Strasburg I & $<0.001$ \\
\hline \multirow[t]{6}{*}{2015} & De Witt I & $<0.001$ \\
\hline & De Witt 2 & $<0.001$ \\
\hline & Green Ridge & $<0.001$ \\
\hline & Strasburg I & $<0.001$ \\
\hline & Strasburg 2 & $<0.001$ \\
\hline & Agror & iency \\
\hline \multirow[t]{4}{*}{2014} & De Witt I & 0.91 \\
\hline & Gallatin & 0.10 \\
\hline & Green Ridge & 0.18 \\
\hline & Strasburg I & 0.67 \\
\hline \multirow[t]{5}{*}{2015} & De Witt I & 0.010 \\
\hline & De Witt 2 & 0.030 \\
\hline & Green Ridge & 0.18 \\
\hline & Strasburg I & 0.11 \\
\hline & Strasburg 2 & 0.30 \\
\hline
\end{tabular}

$\mathrm{N} \mathrm{ha}^{-1}$ was significantly greater than the one-time application of $\mathrm{N}$ at $67 \mathrm{~kg} \mathrm{ha}^{-1}$ and all $101 \mathrm{~kg} \mathrm{ha}^{-1}$. Furthermore, there were no significant differences in $\mathrm{AE}$ among 67 and $101 \mathrm{~kg} \mathrm{~N} \mathrm{ha}^{-1}$ treatments.

The range of PFP and AE of applied $\mathrm{N}$ from this research varied between 30 and $250 \mathrm{~kg}$ biomass kg-1 $\mathrm{N}$ and 24 to $95 \mathrm{~kg}$ biomass $\mathrm{kg}^{-1} \mathrm{~N}$, respectively, depending on the site and $\mathrm{N}$ rate (Fig. 7). This range is wider than the 35 to $99 \mathrm{~kg}$ biomass kg${ }^{-1}$ $\mathrm{N}$ for PFP and 14 to $33 \mathrm{~kg}$ biomass $\mathrm{kg}^{-1} \mathrm{~N}$ for AE as reported by Sadeghpour et al. (2014). This is, in part, because of the lower $\mathrm{N}$ rates used in this research compared to theirs (34-101 $\mathrm{kg} \mathrm{N} \mathrm{ha}^{-1}$ vs. $67-134 \mathrm{~kg} \mathrm{~N} \mathrm{ha}^{-1}$ ). Furthermore, numerically lowered PFP and AE values associated with each site during 2015, the wetter year of the two of this research, are consistent with lower PFP findings highlighted by Sadeghpour et al. (2014) as a result of wet conditions. In addition, AE values for the two sites at De Witt in 2015 (Fig. 7) confirm the above statement by exhibiting comparatively lower values in relation to the wetter/poorly drained site and vice versa. Overall, results related to $\mathrm{N}$ use metrics from this study agree with diminishing returns with increased $\mathrm{N}$ inputs highlighted by Lemus et al. (2008a).

\section{CONCLUSIONS}

Dry matter yield of NPWSG increased with increasing $\mathrm{N}$ for eight of nine sites, and reached a plateau after $34 \mathrm{~kg} \mathrm{~N} \mathrm{ha}^{-1}$ or $67 \mathrm{~kg} \mathrm{ha}^{-1}$. Although higher $\mathrm{N}$ rates caused yield increases, $\mathrm{AE}$ and PFP of applied $\mathrm{N}$ tended to decrease with increasing $\mathrm{N}$ supply. However, supplementation of $\mathrm{N}$ at $67 \mathrm{~kg} \mathrm{ha}^{-1}$ per growing season provides an opportunity to maintain a balance between both yield and efficiency of $\mathrm{N}$ inputs. Therefore, it is important to consider both dry matter yield and $\mathrm{N}$ use metrics such as AE and PFP when producing these biomass grass species on a commercial scale to achieve economic and environmental sustainability of the system.

Under each harvest strategy, split application of $\mathrm{N}$ did not generally improve biomass yields compared to one-time application strategies. At the same time, delayed harvest timing until November or a killing frost in both one harvest and two harvests per growing season maintained greater biomass yields during the $2 \mathrm{yr}$. Such harvesting strategies are well known for facilitating inter-seasonal nutrient recycling between aboveground components and belowground components. In contrast, harvest timing strategies with an early fall (September) harvest resulted in lower biomass yields. Since harvesting of biomass is one of the operations that consume significant amounts of time and energy, decisions on harvesting frequency needs to be made based on energy balances and availability of labor and machinery within the growing season. However, effective implementation of combinations of $\mathrm{N}$ and harvest strategies is

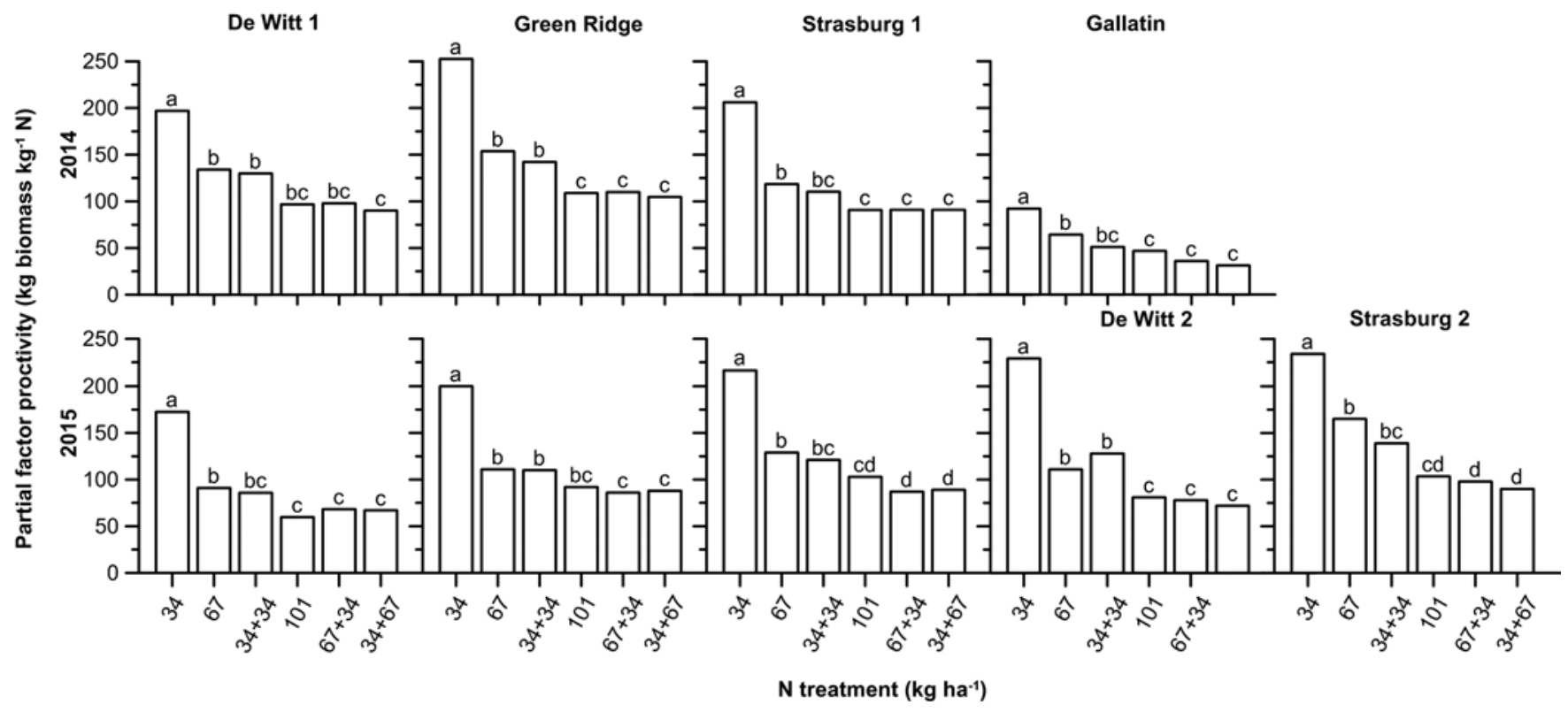

Fig. 6. Partial factor productivity under $\mathrm{N}$ treatments for each site during the experimental period. Bars with the same letter in each column are not significantly different at $P \leq 0.05$. 


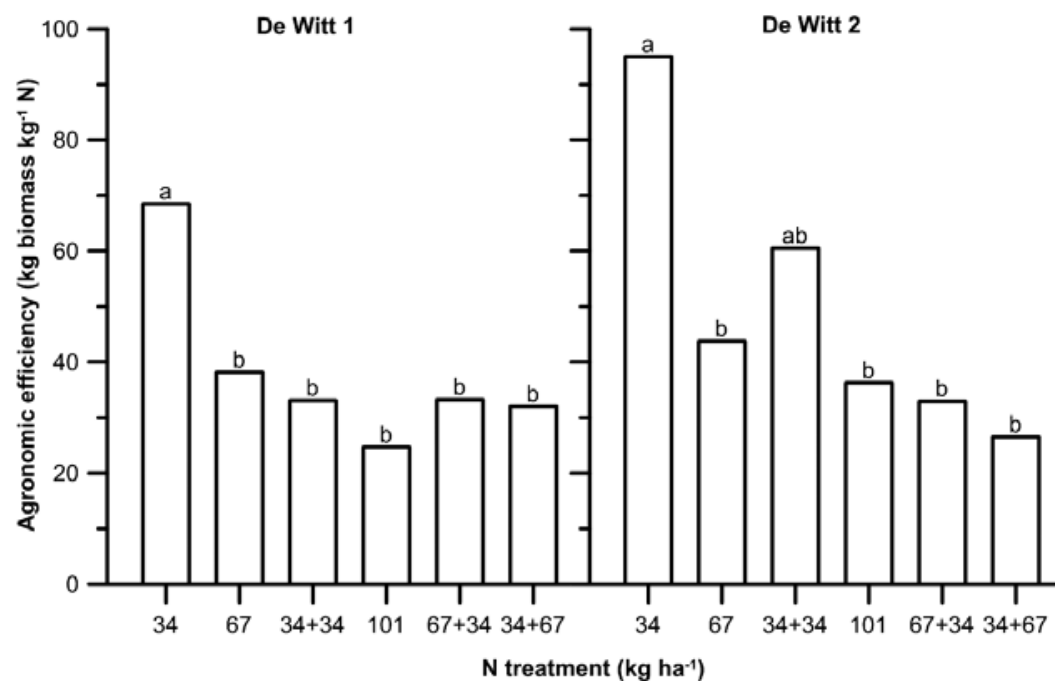

Fig. 7. Agronomic efficiency under each $\mathrm{N}$ treatment at De Witt sites I and 2 in 20I5. Columns with the same letter are not significantly different at $P \leq 0.05$

important to achieve long-term sustainability of warm-season grass biomass energy feedstock production systems.

Finally, characterization of field sites in relation to both spatial and temporal variability in soil, plant populations, and weather conditions helps lead to meaningful response to management for a given year as well as for the long-term sustainability of the bioenergy grass production systems. Most importantly performing a life-cycle analysis, which uses data from field experiments similar to this study, will be helpful for policymakers, scientists, and landowners and/or farmers in gaining a greater perspective on environmental and economic sustainability.

\section{REFERENCES}

Adler, P.R., M.A. Sanderson, A.A. Boateng, P.J. Weimer, and H.-J.G. Jung. 2006. Biomass yield and biofuel quality of switchgrass harvested in fall or spring. Agron. J. 98:1518-1525. doi:10.2134/agronj2005.0351

Alam, S.M. 1999. Nutrient uptake by plants under stress conditions. In: M. Pessarakli, editor, Handbook of plant and crop stress. Marcel Dekker, Inc., New York. p. 285-313.

Anderson, E.K., A.S. Parrish, T.B. Voigt, V.N. Owens, C.-H. Hong, and D.K. Lee. 2013. Nitrogen fertility and harvest management of switchgrass for sustainable bioenergy feedstock production in Illinois. Ind. Crops Prod. 48:19-27. doi:10.1016/j.indcrop.2013.03.029

Bardhan, S., and S. Jose. 2012. The potential for floodplains to sustain biomass feedstock production systems. Biofuels 3:575-588. doi:10.4155/ bfs.12.51

Bonin, C.L., R. Lal, and B.F. Tracy. 2014. Evaluation of perennial warmseason grass mixtures managed for grazing or biomass production. Crop Sci. 54:2373-2385. doi:10.2135/cropsci2014.02.0121

Cameron, K.C., H.J. Di, and J.L. Moir. 2013. Nitrogen losses from the soil/ plant system: A review. Ann. Appl. Biol. 162:145-173. doi:10.1111/ aab.12014

Casler, M.D., and A.R. Boe. 2003. Cultivar $\times$ environment interactions in switchgrass. Crop Sci. 43:2226-2233. doi:10.2135/ cropsci2003.2226

Ceotto, E., and M. Di Candilo. 2010. Sustainable bioenergy production, land and nitrogen use. In: E. Lichtfouse, editor, Biofuels, agroforestry and conservation agriculture: Sustainable agriculture reviews. Springer Science and Business Media B.V., Dordrecht, the Netherlands. p. 101-122. doi:10.1007/978-90-481-9513-8_3

Conway, L.S., M.A. Yost, N.R. Kitchen, K.A. Sudduth, A.L. Thompson, and R.E. Massey. 2017. Topsoil thickness effects on corn, soybean, and switchgrass production on claypan soils. Agron. J. 109:782-794. doi:10.2134/agronj2016.06.0365
Dobermann, A. 2007. Nutrient use efficiency: Measurement and management. In: IFA, Fertilizer best management practices. Brussels, Belgium. 7-9 Mar. 2007. Int. Fertilizer Industry Assoc., Paris.

Gunderson, C.A., E.B. Davis, H.I. Jager, T.O. West, R.D. Perlack, C.C. Brandt, S.D. Wullschleger, L.M. Baskaran, E.G. Wilkerson, and M.E. Downing. 2008. Exploring potential US switchgrass production for lignocellulosic ethanol. Technical Manuscript ORNL/ TM-2007/183. Oak Ridge National Laboratory, Oak Ridge, TN.

Guretzky, J.A., J.T. Biermacher, B.J. Cook, M.K. Kering, and J. Mosali. 2011. Switchgrass for forage and bioenergy: Harvest and nitrogen rate effects on biomass yields and nutrient composition- Springer. Plant Soil 339:69-81. doi:10.1007/s11104-010-0376-4

Haque, M., F.M. Epplin, and C.M. Taliaferro. 2009. Nitrogen and harvest frequency effect on yield and cost for four perennial grasses. Agron. J. 101:1463-1469. doi:10.2134/agronj2009.0193

Hochman, G., S.E. Sexton, and D. Zilberman. 2008. The economics of biofuel policy and biotechnology. J. Agric. Food. Ind. Organ. 6:1-24.

Jose, S., and T. Bhaskar, editors. 2015. Biomass and biofuels: Advanced biorefineries for sustainable production and distribution. CRC Press, Boca Raton, FL.

Lee, D.K., E. Aberle, C. Chen, J. Egenolf, K. Harmoney, and G. Kakani. 2013. Nitrogen and harvest management of conservation reserve program (CRP) grassland for sustainable biomass feedstock production. Global Change Biology Bioenergy 5:6-15. doi:10.1111/j.1757-1707.2012.01177.x

Lee, D.K., V.N. Owens, and J.J. Doolittle. 2007. Switchgrass and soil carbon sequestration response to ammonium nitrate, manure, and harvest frequency on conservation reserve program land. Agron. J. 99:462-468. doi:10.2134/agronj2006.0152

Lee, K.H., T.M. Isenhart, and R.C. Schultz. 2003. Sediment and nutrient removal in an established multi-species riparian buffer. J. Soil Water Conserv. 58:1-8.

Lemus, R., D.J. Parrish, and O. Abaye. 2008a. Nitrogen-use dynamics in switchgrass grown for biomass. Bioenergy Res. 1:153-162. doi:10.1007/s12155-008-9014-x

Lemus, R., E. Charles Brummer, C. Lee Burras, K.J. Moore, M.F. Barker, and N.E. Molstad. 2008b. Effects of nitrogen fertilization on biomass yield and quality in large fields of established switchgrass in southern Iowa, USA. Biomass Bioenergy 32:1187-1194. doi:10.1016/j. biombioe.2008.02.016

Liebig, M.A., M.R. Schmer, K.P. Vogel, and R.B. Mitchell. 2008. Soil carbon storage by switchgrass grown for bioenergy. Bioenergy Res. 1:215-222. doi:10.1007/s12155-008-9019-5

McLaughlin, S., J. Bouton, D. Bransby, B. Conger, W. Ocumpaugh, D. Parrish, C. Taliaferro, K. Vogel, and S. Wullschleger. 1999. Developing switchgrass as a bioenergy crop. In: J. Janick, editor, Perspectives on 
new crops and new uses. ASHS Press, Alexandria, VA. p. 282-299.

McLaughlin, S.B., and L.A. Kszos. 2005. Development of switchgrass (Panicum virgatum) as a bioenergy feedstock in the United States. Biomass Bioenergy 28:515-535. doi:10.1016/j.biombioe.2004.05.006

McLaughlin, S.B., and M.E. Walsh. 1998. Evaluating environmental consequences of producing herbaceous crops for bioenergy. Biomass Bioenergy 14:317-324. doi:10.1016/S0961-9534(97)10066-6

McLaughlin, S.B., D.G. de la Torre Ugarte, C.T. Garten, L.R. Lynd, M.A. Sanderson, V.R. Tolbert, and D.D. Wolf. 2002. High-value renewable energy from prairie grasses. Environ. Sci. Technol. 36:2122-2129. doi:10.1021/es010963d

Mitchell, R., and M. Schmer. 2012. Switchgrass harvest and storage. In: A. Monti, editor, Switchgrass. Green energy and technology book series. Springer, London. p. 113-127. doi:10.1007/978-1-4471-2903-5_5

Mitchell, R., K.P. Vogel, and G. Sarath. 2008. Managing and enhancing switchgrass as a bioenergy feedstock. Biofuels, Bioprod. Bioref. 2:530-539. doi:10.1002/bbb.106

Mitchell, R., K.P. Vogel, and M. Schmer. 2016. Switchgrass (Panicum virgatum) for biofuel production. eXtension Foundation, Kansas City, MO. http://articles.extension.org/pages/26635/switchgrass-panicum-virgatum-for-biofuel-production (Accessed 27 Jan. 2017).

Moraghan, J.T., and L.J. Smith. 1996. Nitrogen in sugarbeet tops and the growth of a subsequent wheat crop. Agron. J. 88:521-526. doi:10.2134/agronj1996.00021962008800040004x

Mulkey, V.R., V.N. Owens, and D.K. Lee. 2008. Management of warmseason grass mixtures for biomass production in South Dakota USA. Bioresour. Technol.99:609-617.doi:10.1016/j.biortech.2006.12.035

Ogden, C.A., K.E. Ileleji, K.D. Johnson, and Q. Wang. 2010. In-field direct combustion fuel property changes of switchgrass harvested from summer to fall. Fuel Process. Technol. 91:266-271. doi:10.1016/j. fuproc.2009.10.007

Parrish, D.J., and J.H. Fike. 2005. The biology and agronomy of switchgrass for biofuels. Crit. Rev. Plant Sci. 24:423-459. doi:10.1080/07352680500316433

Richner, J.M., R.L. Kallenbach, and C.A. Roberts. 2014. Dual use switchgrass: Managing switchgrass for biomass production and summer forage. Agron. J. 106:1438-1444. doi:10.2134/agronj13.0415

Sadeghpour, A., L.E. Gorlitsky, M. Hashemi, S.A. Weis, and S.J. Herbert. 2014. Response of switchgrass yield and quality to harvest season and nitrogen fertilizer. Agron. J. 106:290. doi:10.2134/agronj2013.0183

Sanderson, M.A., J.C. Read, and R.L. Reed. 1999. Harvest management of switchgrass for biomass feedstock and forage production. Agron. J. 91:5-10. doi:10.2134/agronj1999.00021962009100010002x

SAS Institute. 2011. Statistical analysis system. SAS Inst., Inc., Cary, NC.

Schmer, M.R., K.P. Vogel, R.B. Mitchell, and R.K. Perrin. 2008. Net energy of cellulosic ethanol from switchgrass. Proc. Natl. Acad. Sci. USA 105:464-469. doi:10.1073/pnas.0704767105

Scott, H.D., and A. Sallam. 1987. Effects of prolonged flooding on soybean at the R2 growth stage II. $\mathrm{N}$ and P uptake and translocation. J. Plant Nutr. 10:593-608. doi:10.1080/01904168709363593

Seepaul, R., B. Macoon, K.R. Reddy, and W.B. Evans. 2014. Harvest frequency and nitrogen effects on yield, chemical characteristics, and nutrient removal of switchgrass. Agron. J. 106:1805-1816. doi:10.2134/agronj14.0129

Sharma, B.D., S. Kar, and S.S. Cheema. 1990. Yield, water use and nitrogen uptake for different water and $\mathrm{N}$ levels in winter wheat. Fert. Res. 22:119-127. doi:10.1007/BF01116185

Simpson, T.W., A.N. Sharpley, R.W. Howarth, H.W. Paerl, and K.R. Mankin. 2008. The new gold rush: Fueling ethanol production while protecting water quality. J. Environ. Qual. 37:318-324. doi:10.2134/ jeq2007.0599

Soil Survey Staff. 2014. Web soil survey. USDA-NRCS, Washington, DC. https://websoilsurvey.sc.egov.usda.gov (Accessed 8 Dec. 2014).

Thomason, W.E., W.R. Raun, G.V. Johnson, C.M. Taliaferro, K.W. Freeman, K.J. Wynn, and R.W. Mullen. 2005. Switchgrass response to harvest frequency and time and rate of applied nitrogen. J. Plant Nutr. 27:1199-1226. doi:10.1081/PLN-120038544

Tilman, D., J. Hill, and C. Lehman. 2006. Carbon-negative biofuels from low-input high-diversity grassland biomass. Science 314:1598-1600. doi:10.1126/science.1133306

US Department of Energy. 2011. US billion-ton update: Biomass supply for a bioenergy and bioproducts industry. In: R.D. Perlack, and B.J. Stokes, lead authors, Technical Manuscript ORNL/TM-2011/224. Oak Ridge National Laboratory, Oak Ridge, TN.

Utah State University. 2016. Utah State University climate database server. Utah State University, Logan, UT. https://climate.usurf.usu.edu/ index.php (Accessed 15 May 2016).

Vogel, K.P., G. Sarath, A.J. Saathoff, and R.B. Mitchell. 2010. Switchgrass. In: N.G. Halford, and A. Karp, editors, Energy crops. RSC Publishing, Philadelphia, PA. p. 341-380.

Vogel, K.P., J.J. Brejda, D.T. Walters, and D.R. Buxton. 2002. Switchgrass biomass production in the Midwest USA: Harvest and nitrogen management. Agron. J. 94:413-420. doi:10.2134/agronj2002.0413

Waramit, N., K.J. Moore, and A.H. Heggenstaller. 2011. Composition of native warm-season grasses for bioenergy production in response to nitrogen fertilization rate and harvest date. Agron. J. 103:655-662. doi:10.2134/agronj2010.0374

Wayman, S., R.D. Bowden, and R.B. Mitchell. 2014. Seasonal changes in shoot and root nitrogen distribution in switchgrass (Panicum virgatum). Bioenergy Res. 7:243-252. doi:10.1007/s12155-013-9365-9

Wilson, D.M., E.A. Heaton, M. Liebman, and K.J. Moore. 2013. Intraseasonal changes in switchgrass nitrogen distribution compared with corn. Agron. J. 105:285-294. doi:10.2134/agronj2012.0233

Wright, L.L. 1994. Dedicated feedstock supply systems: Their current status in the USA production technology status of woody and herbaceous crops. Biomass Bioenergy 6:191-209. doi:10.1016/0961-9534(94)90075-2 